\title{
Substantial secondary organic aerosol formation in a coniferous forest: observations of both day- and nighttime chemistry
}

\author{
Alex K. Y. Lee ${ }^{1}$, Jonathan P. D. Abbatt ${ }^{1}$, W. Richard Leaitch ${ }^{2}$, Shao-Meng Li ${ }^{2}$, Steve J. Sjostedt ${ }^{1, a}$, \\ Jeremy J. B. Wentzell ${ }^{2}$, John Liggio ${ }^{2}$, and Anne Marie Macdonald ${ }^{2}$ \\ ${ }^{1}$ Department of Chemistry, University of Toronto, Toronto, Canada \\ ${ }^{2}$ Science and Technology Branch, Environment Canada, Downsview, Canada \\ ${ }^{a}$ now at: NOAA ESRL Chemical Sciences Division, Boulder, USA \\ Correspondence to: Alex K. Y. Lee (alexky.lee@utoronto.ca)
}

Received: 18 August 2015 - Published in Atmos. Chem. Phys. Discuss.: 16 October 2015

Revised: 30 March 2016 - Accepted: 13 May 2016 - Published: 3 June 2016

\begin{abstract}
Substantial biogenic secondary organic aerosol (BSOA) formation was investigated in a coniferous forest mountain region in Whistler, British Columbia. A largely biogenic aerosol growth episode was observed, providing a unique opportunity to investigate BSOA formation chemistry in a forested environment with limited influence from anthropogenic emissions. Positive matrix factorization of aerosol mass spectrometry (AMS) measurement identified two types of BSOA (BSOA-1 and BSOA-2), which were primarily generated by gas-phase oxidation of monoterpenes and perhaps sesquiterpenes. The temporal variations of BSOA-1 and BSOA-2 can be explained by gas-particle partitioning in response to ambient temperature and the relative importance of different oxidation mechanisms between day and night. While BSOA-1 arises from gas-phase ozonolysis and nitrate radical chemistry at night, BSOA-2 is likely less volatile than BSOA-1 and consists of products formed via gas-phase oxidation by $\mathrm{OH}$ radical and ozone during the day. Organic nitrates produced through nitrate radical chemistry can account for $22-33 \%$ of BSOA-1 mass at night. The mass spectra of BSOA-1 and BSOA-2 have higher values of the mass fraction of $m / z 91\left(f_{91}\right)$ compared to the background organic aerosol. Using $f_{91}$ to evaluate BSOA formation pathways in this unpolluted, forested region, heterogeneous oxidation of BSOA-1 is a minor production pathway of BSOA-2.
\end{abstract}

\section{Introduction}

Biogenic secondary organic aerosol (BSOA), generated by gas-phase oxidation of biogenic volatile organic compounds (BVOCs, such as isoprene, monoterpenes, and sesquiterpenes) emitted from vegetation, is one of the major contributors to the global SOA budget (Hallquist et al., 2009). As a result of the atmospheric importance of BSOA, many laboratory studies have focused on determining the mass yields and chemical characteristics of BSOA from oxidation of different gas-phase precursors (e.g. Chhabra et al., 2010; Lee et al., 2006a, b). However, chamber SOA is usually less oxidized than ambient SOA (e.g. Aiken et al., 2008; Ng et al., 2011), indicating that the current understanding of BSOA formation remains incomplete. Furthermore, the SOA yield parameters for atmospheric models and the degree of oxygenation of chamber SOA largely depends on the experimental conditions, such as organic aerosol mass loading and seed particle surface area (Ehn et al., 2012; Shilling et al., 2009; Zhang et al., 2014).

Forested environments, such as the boreal forest and Amazon rainforest can be considered giant chemical reactors for BSOA production (e.g. Chen et al., 2009; Ehn et al., 2012; Kanakidou et al., 2005; Slowik et al., 2010). Elevated temperature and/or solar radiation over forests can enhance their BVOC emissions from the forest (Rinne et al., 2002; Leaitch et al., 2011); meanwhile, BSOA can be produced efficiently due to active photochemistry during the day. Despite the fact that many field studies have been performed near or in forested areas to investigate BSOA formation, anthro- 
pogenic influence was frequently observed during those studies, further complicating the SOA formation chemistry (e.g. Han et al., 2014; Setyan et al., 2012). In particular, it has been hypothesized that the interactions of BVOCs with anthropogenic pollutants contributed to high aerosol loadings in the southeastern US (Goldstein et al., 2009). Shilling et al. (2013) observed that the enhancement of SOA formation from isoprene was strongly related to the $\mathrm{NO}_{x}$ concentrations in Sacramento, California. Xu et al. (2015) recently reported that isoprene-derived SOA was directly mediated by sulfate, and $\mathrm{NO}_{x}$ was shown to enhance nighttime SOA formation via nitrate radical oxidation of monoterpenes in the southeastern US.

In addition to the uncertainties of anthropogenic-biogenic interactions on BSOA formation, there is growing evidence of uncaptured BSOA formation chemistry in smog chamber experiments. For example, Ehn et al. (2014) recently showed that the wall effects of smog chambers can result in a substantial loss of highly oxygenated organic compounds with vapour pressures orders of magnitude lower than previously identified gas-phase oxidation products of BVOCs (i.e. referred to as extremely low-volatility organic compounds, ELVOCs). Furthermore, Zhang et al. (2014) illustrated that the formation yields of toluene-derived SOA depend on the seed-to-chamber surface area ratio predominantly due to the loss of SOA-forming vapour to the chamber wall. The observed yield suppression likely extends to BSOA formation systems. Müller et al. (2012) reported that cis-pinonic acid, one of the first-generation products from $\alpha$-pinene ozonolysis, experienced a significant wall loss in smog chambers. Such wall losses have not been adequately taken into consideration when aerosols yields were reported from earlier chamber studies. As a result, conducting a field measurement in a forested environment without significant influence of anthropogenic emissions and without the constraints of smog chamber walls is an attractive approach that can be used to re-evaluate our current knowledge of BSOA formation.

In this study, we deployed an Aerodyne high-resolution time-of-flight aerosol mass spectrometer (HR-ToF-AMS) to characterize ambient aerosol in a coniferous forest mountain region in Whistler, British Columbia from 15 June to 28 July 2010. Simultaneous measurements of gas-phase VOCs were made with a high-resolution proton transfer reaction mass spectrometer (PTR-ToF-MS). The measurement was part of the Whistler Aerosol and Cloud Study (WACS) 2010 campaign. The study duration covered a period when the forested region in Whistler experienced persistently high levels of nearly pure BSOA up to about $5 \mu \mathrm{g} \mathrm{m}^{3}$, providing a unique opportunity to investigate BSOA formation in a coniferous forest. This amount of SOA formation is considerably larger than that observed in pure isoprene-emission-dominated forests, such as in the Amazon (Martin et al., 2010). Rather, it matches the very high levels of BSOA observed in the summertime in another northern location in central Canada (Slowik et al., 2010). Positive matrix factorization (PMF) analysis was performed to understand the types of organic aerosol that contributed to the total organic aerosol mass during this time. The relative importance of different oxidation chemistry (i.e. ozonolysis, $\mathrm{OH}$ radical and nitrate radical oxidation) on BSOA formation between day and night are evaluated. Compared to previous laboratory studies, the mass spectral characteristics of the BSOA factors identified in the current study provide insight into the BSOA formation mechanisms.

\section{Experiment}

\subsection{Sampling location and period}

The Whistler Aerosol and Cloud Study (WACS) was a large-scale field campaign conducted in Whistler, British Columbia from 15 June to 28 July 2010. One of the two sampling sites on Whistler Mountain (Raven's Nest, see Fig. S1 in the Supplement) sits within a coniferous forest mountain area at an elevation of $1320 \mathrm{~m}$ a.s.l. In this paper, we focus on the observations at Raven's Nest from 1 to 19 July 2010, covering a large BSOA event that lasted approximately 5 days (6-10 July) and contrast them with those from a period with mixed biogenic and regional background influence (1318 July) (Figs. 1 and S2, and see Sect. 3 for discussion). Key measurements used in this analysis are briefly described in the following sections.

\subsection{Aerosol measurements}

An Aerodyne high-resolution time-of-flight aerosol mass spectrometer (HR-ToF-AMS, Aerodyne Research Inc.) and scanning mobility particle sizer (SMPS; TSI Inc., model 3936L75) were deployed to measure real-time, nonrefractory particulate matter (NR-PM, i.e. ammonium, nitrate, sulfate, and organic) and particle number size distributions $(16-685 \mathrm{~nm})$, respectively. The ambient air was drawn through a stainless steel sampling line by the HR-ToF-AMS, SMPS and other collocated particle instruments. The working principle of the HR-ToF-AMS has been reported in detail previously (DeCarlo et al., 2006). In brief, an aerodynamically focused particle beam impacts a tungsten vaporizer that was maintained at $\sim 600^{\circ} \mathrm{C}$ to vaporize the NR-PM, and the resulting vapours are ionized with electron impact ionization. The ions are then detected by a high-resolution time-of-flight mass spectrometer, which was operated in $\mathrm{V}$ mode $(5 \mathrm{~min}$, mass resolving power $\sim 2000$ with a higher sensitivity) and $\mathrm{W}$ mode $(5 \mathrm{~min}$, mass resolving power $\sim 4000$ with a lower sensitivity) alternatively. Ionization efficiency (IE) calibrations were performed onsite using monodisperse ammonium nitrate particles. The default relative IE (RIE) of nitrate, sulfate, ammonium, chloride, and organic were used.

The data were processed using the AMS data analysis software (Squirrel, version $1.51 \mathrm{H}$ for unit mass resolution (UMR) data and Pika, version 1.10H for high-resolution 


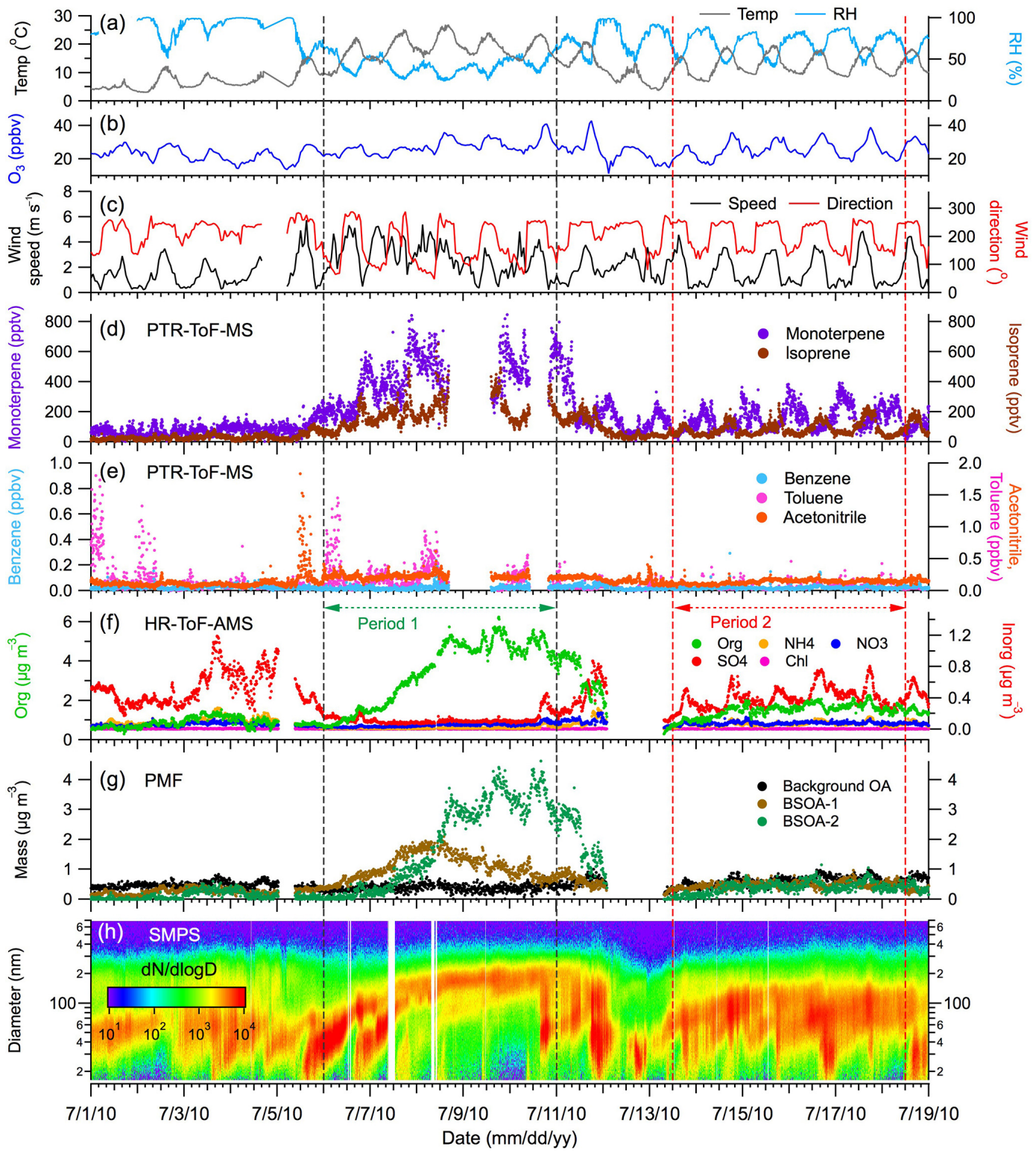

Figure 1. Time series (PST) profiles of (a) temperature and relative humidity, (b) ozone, (c) wind speed and direction, (d) monoterpene and isoprene measured by PTR-ToF-MS, (e) benzene toluene and acetonitrile measured by PTR-ToF-MS, (f) organic, nitrate, sulfate, ammonium, and chloride measured by HR-ToF-AMS, (g) background OA, BSOA-1, and BSOA-2 determined by PMF analysis, (h) particle number size distribution measured SMPS. The gray and red dashed lines represent the boundaries of Period 1 (6-10 July) and Period 2 (13-18 July), respectively. Figure S2 enlarges the time series during (a) 6-10 July and (b) 13-18 July.

peak fitting, http://cires.colorado.edu/jimenez-group/ ToFAMSResources/ToFSoftware/index.html) with the corrected air fragment column of the standard fragmentation table (Allan et al., 2004; DeCarlo et al., 2006). The data reported here are obtained from the high-resolution mass spectral fitting of W-mode data. Elemental analysis (oxygenand hydrogen-to-carbon ratios, $\mathrm{O}: \mathrm{C}$ and $\mathrm{H}: \mathrm{C}$ ) is based on the improved method proposed by Canagaratna et al. (2015). Given that most HR-ToF-AMS studies reported $\mathrm{O}: \mathrm{C}$ and $\mathrm{H}: \mathrm{C}$ values using Aiken's method (Aiken et al., 2008), comparison between the Aiken's and improved method is shown in Fig. S5. Positive matrix factorization (PMF) was performed to analyse the high-resolution AMS organic measurement for identification of the forms of organic aerosol in this study. The bilinear model was solved using the PMF2 algorithm in robust mode (Paatero and Tapper, 1994) and the final solution was selected using the PMF Evaluation Tool (PET) version 2.06 (Ulbrich et al., 2009). A three-factor solution was selected as the optimum solution based on examination of the PMF quality of fit parameter 
( $Q / Q_{\text {expected }}$ ) as a function of the number of PMF factors up to seven factors (Fig. S9). Further increasing the number of factors from three to four factors only splits a factor representing background organic aerosol, and thus more than three factors were not considered in this study. Time series and mass spectra of two-, three-, and four-factor PMF solutions are shown in Figs. S10-S12, respectively.

\subsection{VOC measurements}

Measurements of volatile organic compounds (VOCs) were performed using a high-resolution proton transfer time-offlight mass spectrometer (PTR-ToF-MS, Ionicon Analytik $\mathrm{GmbH}$ ). The ambient air was drawn through a $5 \mathrm{~m}$ long Perfluoroalkoxy (PFA) sampling line by a diaphragm pump at a rate of $5 \mathrm{slpm}$. A $200 \mathrm{sccm}$ sample was drawn into the instrument through a heated inlet from the sampling line. Fiveminute backgrounds were collected hourly through a platinum wool catalyst heated to $350{ }^{\circ} \mathrm{C}$. The time resolution of measurement was $1 \mathrm{~min}$. The $E / N$ (where $E$ is electric field strength and $N$ is buffer gas density) in the drift tube is kept at about 135 Townsend (Td). The raw PTR-ToF-MS data were acquired by the TofDaq software (Tofwerk AG, Switzerland) and post processed by PTR-MS ToF Viewer (Ionicon Analytik $\mathrm{GmbH}$ ). Operations of proton transfer reaction mass spectrometer (PTR-MS) with a quadrupole mass spectrometer have been presented in great detail (Blake et al., 2009; de Gouw and Warneke, 2007). Briefly, a PTR-MS is a soft ionization technique that allows for detection of VOCs that have a greater proton affinity than water. While the ionization process is the same in the PTR-ToF-MS as the PTR-MS, the high-resolution time-of-flight mass spectrometer used in the PTR-ToF-MS captures the entire mass spectrum from 12 to a high mass number (usually about 400) at high time resolutions (e.g. $1 \mathrm{~s}$ ). The high mass resolution of the mass detector $(\sim 4000-5000)$ allows isobars to be resolved. A list of massto-charge $(\mathrm{m} / \mathrm{z})$ ratios of some selected VOCs is shown in Table S1 in the Supplement.

Periodic calibrations of the PTR-ToF-MS were performed onsite for $\alpha$-pinene, isoprene, methanol, acetone, methyl vinyl ketone (MVK), and 2-methyl-3-buten-2-ol (MBO). Post-campaign calibration of formic acid was obtained utilizing heated permeation tubes. The sensitivity of formic acid was then ratioed to the acetone sensitivity measured both during and after the campaign, and the ratio together with the acetone field calibration was used to retrieve formic acid from the field measurements. The sensitivities and limits of detection (LOD) of calibrated VOCs are shown in Table S1. Three $1 \mathrm{~h}$ integrated VOCs samples were also collected each day in $3 \mathrm{~L}$ stainless steel canisters. Analysis for both polar and nonpolar compounds was carried out offsite by gas chromatography. It should be noted that the PTR-ToF-MS isoprene signal at $\mathrm{m} / \mathrm{z} 69.070 \mathrm{can}$ be influenced significantly by MBO fragments so that a correction factor based on the linear correlation between the isoprene concentrations deter- mined by PTR-ToF-MS and canister samples (i.e. canister isoprene $=0.7 \cdot$ PTR-ToF-MS isoprene, $R^{2}=0.79$ ) was used to correct the real-time isoprene concentration measured by the PTR-ToF-MS for the MBO interference.

\subsection{Ozone and $\mathrm{OH}$ radical measurements}

Ozone was measured by a UV absorption monitor (Model TECO 49C, Thermo Environmental Instruments Inc.). During the last 10 days of the campaign (19-28 July), hydroxyl $(\mathrm{OH})$ radicals were measured using the wellestablished technique of chemical ionization mass spectrometry (OH-CIMS) (Tanner et al., 1997). The measurement was used to estimate the diurnal pattern of $\mathrm{OH}$ radical concentration from 13 to 18 July for evaluating BSOA formation chemistry. The instrument has been previously described (Berresheim et al., 2000; Sjostedt et al., 2007; Tanner et al., 1997). Briefly, hydroxyl radicals are measured by titration with isotopically labelled ${ }^{34} \mathrm{SO}_{2}$ to produce $\mathrm{H}^{34} \mathrm{SO}_{4}$. The isotopically labelled sulfuric acid molecules were then ionized by charge transfer with nitrate ions $\left(\mathrm{NO}_{3}^{-}\right)$, produced by passing a flow of nitrogen containing $\mathrm{HNO}_{3}$ through a ${ }^{210} \mathrm{Po}$ ion source. In order to minimize wall losses of $\mathrm{OH}$ radicals, a flow of $2400 \mathrm{slpm}$ is drawn through an inlet with $7.6 \mathrm{~cm}$ inner diameter and about $\sim 0.6 \mathrm{~m}$ in length. The instrument background was determined periodically by adding hexafluoropropene $\left(\mathrm{C}_{3} \mathrm{~F}_{6}\right)$ through the front injectors to scavenge the ambient $\mathrm{OH}$ radicals. Calibrations were performed in situ by photolysing water vapour with a mercury pen ray lamp in the sampling inlet. The detection limit for a $5 \mathrm{~min}$ integration of $\mathrm{OH}$ radical was $5 \times 10^{4}$ molecules $\mathrm{cm}^{-3}$.

\section{Results and discussion}

Figure 1 shows the time series of various measurements from 1 to 19 July, which can be divided into three periods based on the meteorological conditions previously reported (Ahlm et al., 2013; Pierce et al., 2012). The first period (1-5 July) was humid and cloudy with low temperature. A relatively high concentration of secondary sulfate indicates that this period was strongly influenced by aged/transported air masses. The second period (6-10 July) started with increasing ambient temperature and was accompanied by rapidly increasing levels of biogenic volatile organic compounds (BVOCs, e.g. monoterpenes and isoprene) which were followed by increasing total organic aerosol mass (Fig. 1a, d, and f). This period is referred to as the "biogenic period (or Period 1)" hereafter and will be the focus of Sect. 3.1 and 3.2. The aerosol sulfate concentration was low during the biogenic period. The third period (13-19 July) was cooler than the biogenic period. Although the diurnal cycles of different measurements indicate that the third period had both biogenic and regional background influence (referred to as Period 2 hereafter), the observations provide insights into the path- 
ways of biogenic secondary organic aerosol (BSOA) formation during the biogenic period (Sect. 3.3). The $\mathrm{NO}_{x}$ (average $\pm \mathrm{SD}$ (standard deviation $)=0.7 \pm 0.9 \mathrm{ppbv})$, benzene $(0.02 \pm 0.01 \mathrm{ppbv})$, toluene $(0.11 \pm 0.16 \mathrm{ppbv})$, and acetonitrile $(0.08 \pm 0.04 \mathrm{ppbv})$ mixing ratios were generally low within 1-19 July, indicating limited influence by local anthropogenic emissions and biomass burning. The significance of nighttime nitrate radical chemistry will be discussed in Sect. 3.4. Lastly, a comparison between previous laboratory studies and these field observations will be discussed in Sect. 3.5.

\subsection{Biogenic period}

Enhancement of BVOC (monoterpenes and isoprene) emissions from the forest due to high temperature and/or solar radiation was observed throughout the campaign (Fig. 1a and d). Specifically, significant positive correlations of daily average temperature and monoterpenes $\left(R^{2}=0.91\right)$ and isoprene $\left(R^{2}=0.84\right)$ mixing ratios were obtained (Fig. S3). The forested area in Whistler is dominated by conifers. Therefore, monoterpenes, rather than isoprene, are the dominant BVOCs emitted into air. For example, for the biogenic period, monoterpenes observed at the site were about a factor of 3 higher than isoprene. Considering the low SOA formation yield from gas-phase isoprene photo-oxidation chemistry determined in smog chamber experiments, monoterpenes likely play a more critical role than isoprene in BSOA formation in Whistler (Lee et al., 2006a, b). Note that sesquiterpenes could not be determined by the PTR-ToF-MS; thus their contributions to BSOA formation cannot be evaluated.

The uniform air mass within the biogenic period led to the accumulation of organic aerosol (Fig. 1f) (Pierce et al., 2012). The organic aerosols formed during the pristine event were almost entirely biogenic in origin as determined by the FTIR analysis of filter samples during this period (Ahlm et al., 2013). Inorganic constituents generally accounted for less than $5 \%$ of the total NR-PM by mass. Even though the sulfate concentration was slightly enhanced during the strong new particle formation events on 5 and 6 July (i.e. particle number rapidly increased in the $20-30 \mathrm{~nm}$ size range), the particle growth to diameters larger than $100 \mathrm{~nm}$ was primarily due to condensation of BSOA materials on the nucleation mode particles (Fig. If and h) (Pierce et al., 2012). There are strong correlations among methanol, acetone, and total OA mass throughout the study (Figs. 2 and S4), suggesting that they are likely from a similar origin. The methanol-toacetone ratio determined in this study is $3.61\left(R^{2}=0.94\right)$ as shown in Fig. 2. The correlation between total organic aerosol mass and formic acid $\left(R^{2}=0.77\right)$ is also presented in Fig. S4. Note that methanol sources can be dominated by terrestrial vegetation in forest areas. Overall, the biogenic episode provides a unique opportunity to investigate the properties and formation mechanisms of BSOA in a forested area dominated by terpene emissions.

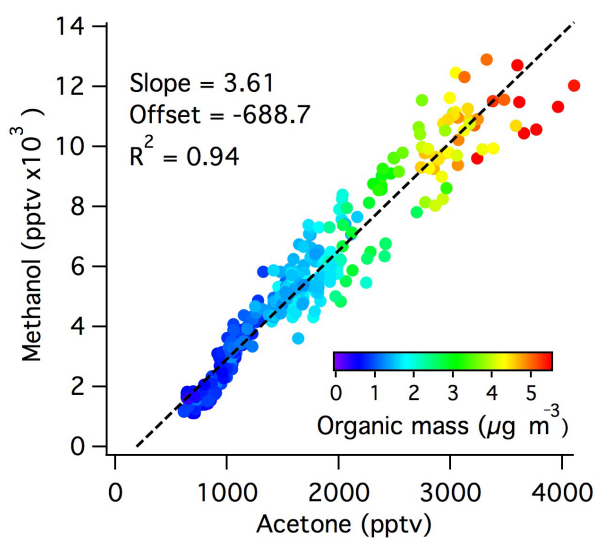

Figure 2. Correlation of methanol and acetone measured by PTRToF-MS. The colour scales represent the total organic mass measured by HR-ToF-AMS.

\subsection{Chemical characteristics of BSOA}

Positive matrix factorization (PMF) was performed to understand the chemical characteristics of BSOA. The PMF analysis separates the total organic aerosol into three factors: background organic aerosol (background OA), biogenic SOA-1 (BSOA-1), and biogenic SOA-2 (BSOA-2). The organic speciated mass spectra and time series of these factors are shown in Figs. 3a-c and 1g, respectively. The background OA represents aged organic aerosol with an intense signal of $\mathrm{CO}_{2}^{+}$fragments (i.e. a tracer of organic acid) and a high degree of oxygenation $(\mathrm{O}: \mathrm{C}=0.87)$, and largely correlates with secondary sulfate (see Sect. 3.3). The BSOA-1 and BSOA-2 factors represent two different types of fresh BSOA based on their mass spectral features and temporal profiles (see Sect. 3.3). Elemental analysis shows that the degree of oxygenation of BSOA-2 $(\mathrm{O}: \mathrm{C}=0.58)$ and BSOA-1 $(\mathrm{O}: \mathrm{C}=0.56)$ is similar even though they have very different $\mathrm{m} / \mathrm{z}$ 44-to- $\mathrm{m} / \mathrm{z} 43$ ratios (a parameter for evaluating the degree of aging of oxygenated OA (OOA) from unit mass resolution AMS spectra) ( $\mathrm{Ng}$ et al., 2010). This observation can be due to the fact that $\mathrm{CH}_{2} \mathrm{O}^{+}$and $\mathrm{C}_{2} \mathrm{H}_{3} \mathrm{O}^{+}$fragments are the primary contributors of organic $m / z 30$ and 43 , respectively, for both BSOAs. Note that the isoprene SOA signature (i.e. a high mass fraction of $m / z 82\left(\mathrm{C}_{5} \mathrm{H}_{6} \mathrm{O}^{+}\right)$to total organic mass, $f_{82}$ ) was not observed in the mass spectrum of BSOA-1 and BSOA-2 (Robinson et al., 2011; Slowik et al., 2012; Hu et al., 2015). The $f_{82}$ values of background OA, BSOA-1, and BSOA-2 are 0.003, 0.007, and 0.006, respectively, which match previous AMS measurements from studies strongly influenced by monoterpene emissions (Hu et al., 2015).

The van Krevelen diagram in Fig. 3d shows that the ambient data (orange dots for the biogenic period only) can be a linear combination of the three PMF factors. Comparison between the Aiken's and improved method for elemental com- 

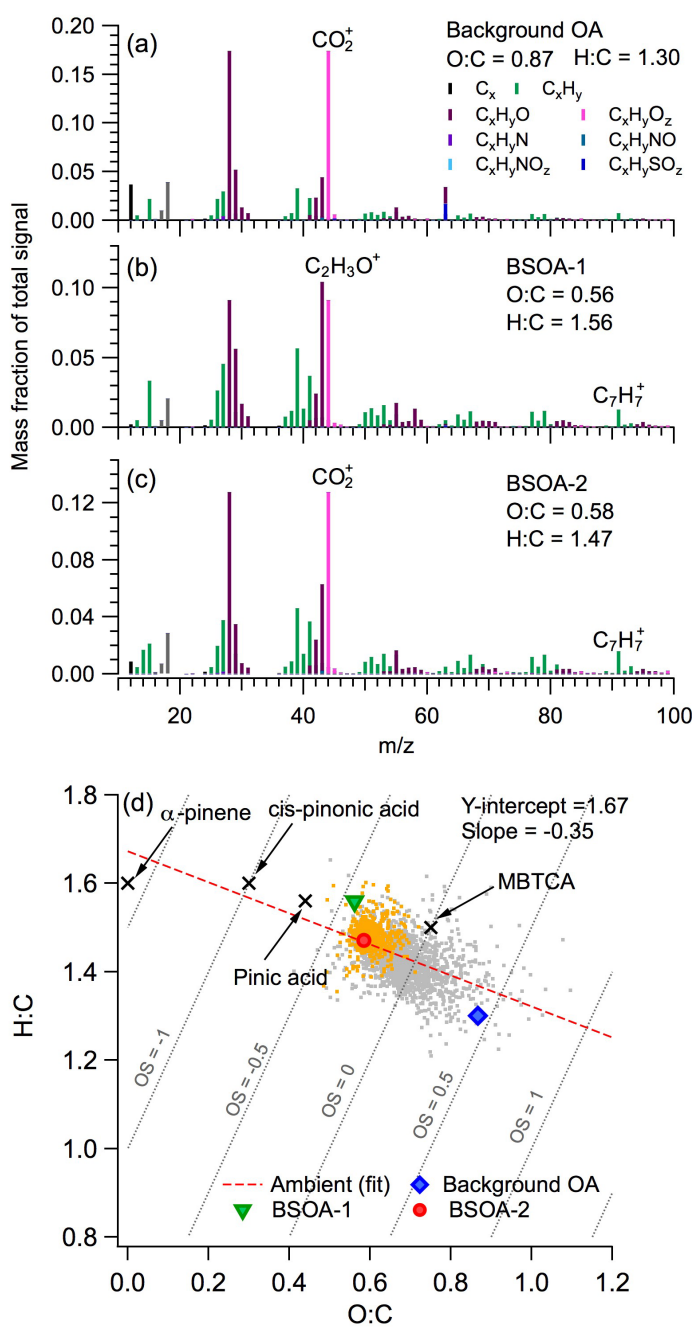

Figure 3. Normalized unit mass resolution mass spectra of PMF factors (a) background OA, (b) BSOA-1, and (c) BSOA-2. (d) Van Krevelen diagram: orange and gray dots represent observations from the regional biogenic period (6-10 July) and the whole study period, respectively. The cross symbols represent the $\mathrm{O}: \mathrm{C}$ and $\mathrm{H}: \mathrm{C}$ ratios of $\alpha$-pinene and its major oxidation products (cispinonic acid, pinic acid, 3-methyl-1,2,3-butanetricarboxylic acidMBTCA). Comparison between the Aiken's and improved method for elemental composition analysis is shown in Fig. S5.

position characterization is shown in Fig. S5. The linear fit of ambient data from the whole campaign (slope $=-0.35$ and $y$ intercept $=1.67$ ) is shown in Fig. $3 \mathrm{~d}$. The $y$ intercept is close to the theoretical $\mathrm{H}: \mathrm{C}$ of most BVOCs such as isoprene $\left(\mathrm{C}_{5} \mathrm{H}_{8}\right), \alpha$-pinene $\left(\mathrm{C}_{10} \mathrm{H}_{16}\right)$, limonene $\left(\mathrm{C}_{10} \mathrm{H}_{16}\right)$, and $\beta$-caryophyllene $\left(\mathrm{C}_{15} \mathrm{H}_{24}\right)$. Furthermore, some major products of $\alpha$-pinene ozonolysis including cis-pinonic acid, pinic acid, 3-methyl-1,2,3-butanetricarboxylic acid (MBTCA) fall along the linear fit of the ambient data, consistent with the VOC measurements that terpenes are likely one of the major BSOA precursors in the Whistler forest (see Sect. 3.1). Cis-pinonic and pinic acids are $\alpha$-pinene first-generation ox- idation products with the average saturation vapour concentrations $\left(C^{*}\right)$ categorized as intermediate VOCs (IVOCs, $C^{*}=10^{3}-10^{6} \mu \mathrm{g} \mathrm{m}^{3}$ ) and semi-VOCs (SVOCs, $C^{*}=10^{2}-$

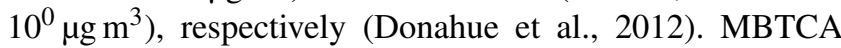
is a low-volatility $\left(C^{*}=10^{-1}-10^{-3} \mu \mathrm{g} \mathrm{m}^{3}\right)$, later-generation product of $\alpha$-pinene SOA and a tracer of terpene SOA. It is important to note that the observed growth for small particles $(<50 \mathrm{~nm})$ at the early stage of the biogenic period in Whistler must have an average $C^{*}$ less than $10^{-2} \mu \mathrm{g} \mathrm{m}$ based on the modelling results from Pierce et al. (2012). This implies that at least small amounts of organic materials with volatility much lower than BSOA-1 and 2 (e.g. ELVOC observed by Ehn et al., 2014) were required to permit the observed initial growth.

\subsection{Understanding BSOA formation from its diurnal character}

At the beginning of the biogenic period when there was significant nucleation, BSOA-1 was more prevalent than BSOA2. BSOA-2, however, sustained the particle growth at the elevated temperature after the new particle formation event on 7 July, likely because of its low volatility. BSOA-1 started to decline from 8 July and the total organic mass was dominated by BSOA-2 during the rest of the biogenic period. The temporal profile of the BSOA-1-to-BSOA-2 ratio is shown in Fig. S6 to illustrate the relative contribution of these BSOA factors within the biogenic period. These observations imply different formation chemistry of the two BSOA materials within the biogenic period (see later discussion).

The clear diurnal patterns of both gas- and particle-phase species within the period with a mix of biogenic and regional background influence (Period 2) permit evaluation of both the influence of photochemistry and meteorological conditions on the formation of BSOA-1 and BSOA2. Figure $4 \mathrm{~b}$ illustrates the morning increase in $\mathrm{OH}$ radical concentrations and ozone mixing ratios due to increases in solar radiation (i.e. indicated by the elevated ambient temperature), suggesting more active photo-oxidative chemistry during the daytime and less deposition in the case of ozone. The reaction rate constants of monoterpenes with ozone and $\mathrm{OH}$ radical are on the order of $10^{-15}-10^{-17}$ and $10^{-10}-10^{-11} \mathrm{~cm}^{3}$ molecule ${ }^{-1} \mathrm{~s}^{-1}$, respectively, and both oxidation processes give comparable SOA formation yields for monoterpenes (Lee et al., 2006a, b). Given that the concentrations of ozone and $\mathrm{OH}$ radical during the daytime are on the order of $10^{11}$ and $10^{5}-10^{6}$ molecules $\mathrm{cm}^{-3}$, respectively (Fig. 4b), the overall contributions of ozonolysis and $\mathrm{OH}$ oxidation of monoterpenes to daytime BSOA formation in Whistler can be comparable to each other, even though ozonolysis may play a larger role than $\mathrm{OH}$ oxidation in late afternoon and nighttime.

Monoterpene mixing ratios were highest during the night and then dropped rapidly in the morning (Fig. 4c), which can be a combined effect of chemistry and meteorological 


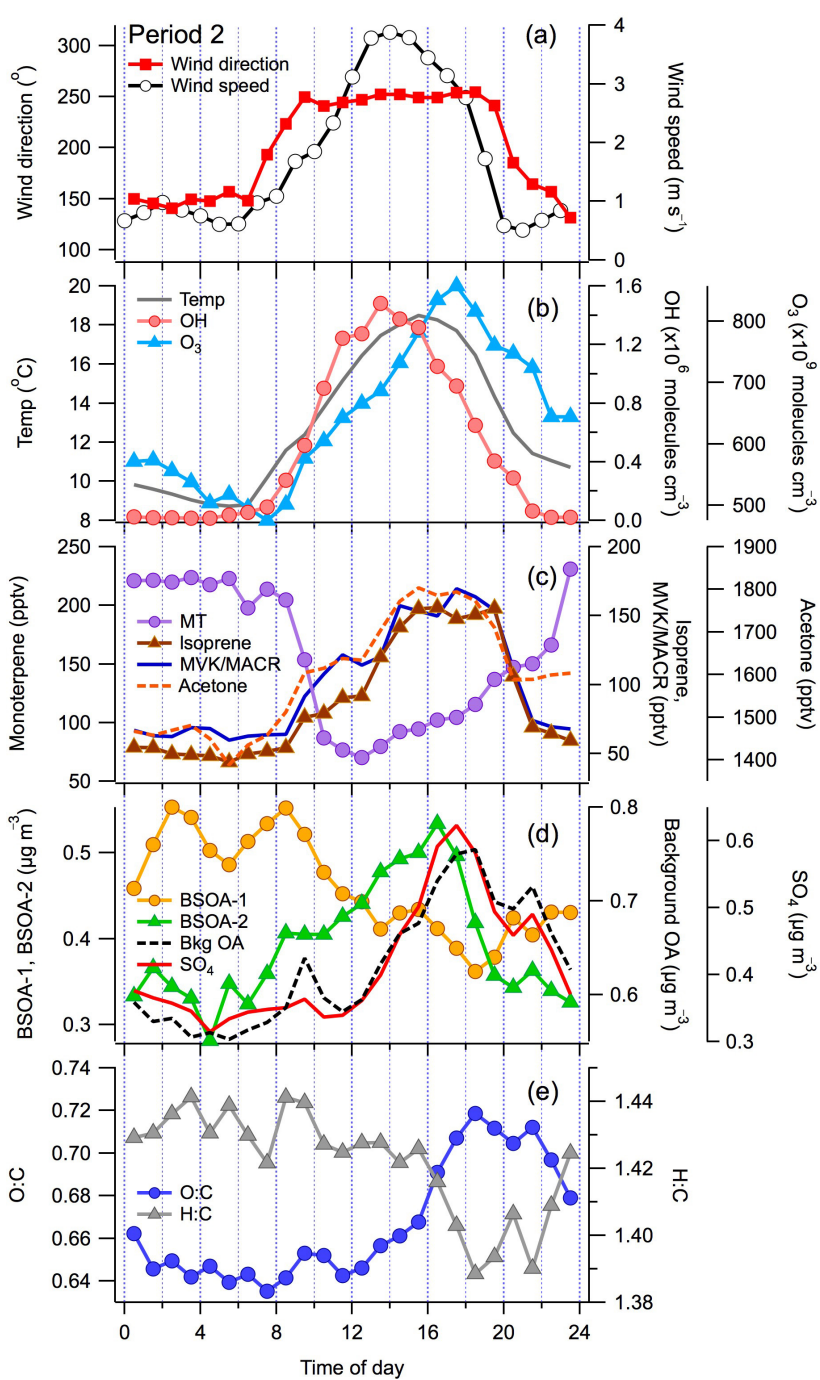

Figure 4. Diurnal cycles of (a) temperature, $\mathrm{OH}$ radical and ozone (b) monoterpene (MT), isoprene, methyl vinyl ketone $(\mathrm{MVK}) /$ methacrolein $(\mathrm{MACR})$, and acetone, $(\mathbf{c})$ background OA, BSOA-1, BSOA-2 and $\mathrm{SO}_{4}$, and (d) elemental compositions of total organics $(\mathrm{O}: \mathrm{C}$ and $\mathrm{H}: \mathrm{C})$ observed during 13-18 July (Period 2). Note that the $\mathrm{OH}$ radical concentration is the average value measured after 19 July.

condition. Firstly, monoterpene emissions generally increase with ambient temperature. This observation indicates that monoterpenes were rapidly oxidized once the concentrations of ozone and $\mathrm{OH}$ radicals built up during the daytime. Secondly, the increased mixing depth in the morning and alternation of mountain flows from downslope $\left(\sim 150^{\circ}\right)$ to upslope $\left(\sim 250^{\circ}\right)$ wind at around 07:00-09:00 LT (local time, UTC $-8 \mathrm{~h}$, Fig. 4a) might contribute to this observation if the surface layer had relatively low monoterpene mixing ratios. However, additional BVOC measurement in the valley is required to confirm this argument. Furthermore, monoterpene mixing ratios gradually increased in the afternoon likely in response to the decreasing levels of atmospheric oxidants rather than the transition of upslope to downslope wind in the late afternoon. It is worth noting that a relatively strong downslope wind was observed when BSOA and BVOCs accumulated in Whistler during the early period of the biogenic episode (Fig. 1c).

Other BVOCs and their oxidation products such as acetone, isoprene and probably $\mathrm{MVK} /$ methacrolein (MACR; PTR-ToF-MS cannot separate MVK and MACR, and other isoprene oxidation products may contribute to this massto-charge ratio signal) increased in connection with ozone, providing further evidence of active photochemistry during the day. The similar diurnal cycles of these VOCs were also clearly observed during the later period of the biogenic episode (i.e. 9-10 July, Fig. 1). Different diurnal cycles of isoprene and monoterpene mixing ratios were observed previously in forests (Harrison et al., 2001). Note that isoprene emission flux is sensitive to both solar radiation and temperature (Rinne et al., 2002).

The diurnal variations of background $\mathrm{OA}$ and secondary sulfate that was nearly neutralized by ammonium (Fig. S13) are almost identical, and their concentrations peak at around 17:00 LT (Fig. 4d). Ozone level also peaks at about the same time. These observations indicate increasing influences of the regional background air mass in Whistler in the late afternoon. Upslope wind likely carried the aged regional aerosol particles to the sampling site and their mass loadings decreased when the transition of upslope to downslope wind occurred. The background OA can be successfully separated from the BSOA components using the PMF analysis. Comparing the total OA, the BSOA components, and the background $\mathrm{OA}$, it is clear that the total organic mass within the biogenic period was not strongly influenced by anthropogenic sources and/or transported air masses (Fig. 1g).

The BSOA-2 diurnal profile matches the variation of ozone plus $\mathrm{OH}$ radical levels during the daytime, suggesting that oxidation of monoterpenes and its oxidation products is likely one of the major BSOA-2 formation pathways. BSOA-1 has a diurnal pattern clearly distinct from BSOA2 , with a nighttime peak. BSOA-1 is likely more volatile than BSOA-2 based on their relative $f \mathrm{CO}_{2}^{+}$values (Huffman et al., 2009). The low temperature at night may favour partitioning of BSOA-1 materials to the particle phase, resulting in a higher concentration of BSOA-1 at night. In addition to the gas-particle partitioning of BSOA-1 materials, BSOA-1 formation via ozonolysis of monoterpenes at night is possible because of the large abundance of monoterpenes and presence of ozone. Nocturnal nitrate radical chemistry can also contribute to BSOA-1 production significantly (see Sect. 3.4). Lastly, BSOA-2 was composed of a higher fraction of organic acids (i.e. $f \mathrm{CO}_{2}^{+}$) compared to BSOA-1. Additional information is required to evaluate the possibility of heterogeneous conversion of BSOA-1 to BSOA-2 during the daytime (see Sect. 3.5). 


\subsection{Nitrate radical chemistry at night}

Nitrate radical $\left(\mathrm{NO}_{3} \cdot\right)$ is a product of ozone and $\mathrm{NO}_{x}$ and is a well-known nocturnal oxidant. Xu et al. (2015) recently reported that $\mathrm{NO}_{3} \cdot$ chemistry could play a key role in producing BSOA at night in the southeastern US. The average ozone and $\mathrm{NO}_{x}$ mixing ratios at night during WACS 2010 were about $20-30 \mathrm{ppbv}$ (Figs. $1 \mathrm{~b}$ and 4 ) and $0.34 \mathrm{ppbv}$ (Fig. 5a) throughout the entire study, respectively, which are comparable to the levels reported by $\mathrm{Xu}$ et al. (2015) (i.e. $\mathrm{O}_{3}=21 \mathrm{ppbv}$ and $\mathrm{NO}_{x}=0.54 \mathrm{ppbv}$ ). Laboratory studies have shown that organic nitrates can be produced from the reaction between $\mathrm{NO}_{3} \cdot$ and BVOCs (Ng et al., 2008; Fry et al., 2009). Fragmentation of organic nitrates produces $\mathrm{NO}^{+}$and $\mathrm{NO}_{2}^{+}$signals in AMS measurement with the $\mathrm{NO}^{+} / \mathrm{NO}_{2}^{+}$ratio much higher than that of inorganic nitrate (e.g. Farmer et al., 2010). The $\mathrm{NO}^{+} / \mathrm{NO}_{2}^{+}$ratio of ammonium nitrate determined in our calibration was approximately 3.38 . In contrast, the average $\mathrm{NO}^{+} / \mathrm{NO}_{2}^{+}$ratio observed in the AMS measurement was 11.4 and it was relatively constant throughout the whole sampling period (Fig. 5a). The diurnal cycle of ambient $\mathrm{NO}^{+} / \mathrm{NO}_{2}^{+}$ratio observed in Period 2 is shown in Fig. 5c. The high values and small diurnal variations of $\mathrm{NO}^{+} / \mathrm{NO}_{2}^{+}$ratio indicate low levels of inorganic nitrate and the presence of organic nitrates in the observed BSOA (e.g. Farmer et al., 2010; Xu et al., 2015).

No diurnal cycles of $\mathrm{NO}^{+}$and $\mathrm{NO}_{2}^{+}$AMS fragments were observed (Fig. S7) to confirm significant $\mathrm{NO}_{3} \cdot$ chemistry at night, possibly due to the upslope mixing of anthropogenic/aged aerosol particles mentioned in the previous sections. There was some covariance in the temporal variations of sulfate and nitrate (Fig. S8). To evaluate the possibility of nighttime $\mathrm{NO}_{3} \cdot$ chemistry in this study, the AMS nitrate mass is normalized by sulfate mass to eliminate the potential effects of upslope mixing on nitrate aerosol concentrations. The $\mathrm{NO}_{3}^{-} / \mathrm{SO}_{4}^{2-}$ ratio correlates extremely well with the BSOA-1 $\left(R^{2}=0.71\right)$ for the whole sampling period (Fig. 5b). Furthermore, the diurnal pattern of this ratio during Period 2 (13-18 July) was almost identical to that of BSOA-1 (Fig. 5d), indicating the formation of organic nitrates at night. The formation of organic nitrates during the biogenic episode under relatively high temperature and low $\mathrm{RH}$ conditions further suggests that the diurnal cycle of the $\mathrm{NO}_{3}^{-} / \mathrm{SO}_{4}^{2-}$ ratio cannot be fully explained by gas-particle partitioning of nitric acid which would occur preferentially at lower temperatures.

Assuming the $\mathrm{NO}^{+} / \mathrm{SO}_{4}^{2-}$ and $\mathrm{NO}_{2}^{+} / \mathrm{SO}_{4}^{2-}$ mass ratios were constant in the air mass carried by upslope winds and are approximately equal to 0.088 and 0.009 , respectively (i.e. the minimum values observed during the upslope wind condition), the $\mathrm{NO}^{+}$and $\mathrm{NO}_{2}^{+}$mass originating from the upslope wind air masses can be subtracted from their total mass loadings. After that, the mass loading of nitrate functional groups $\left(-\mathrm{ONO}_{2}\right)$ in organic compounds and thus the organic nitrate mass contributing to the observed BSOA-1 mass can
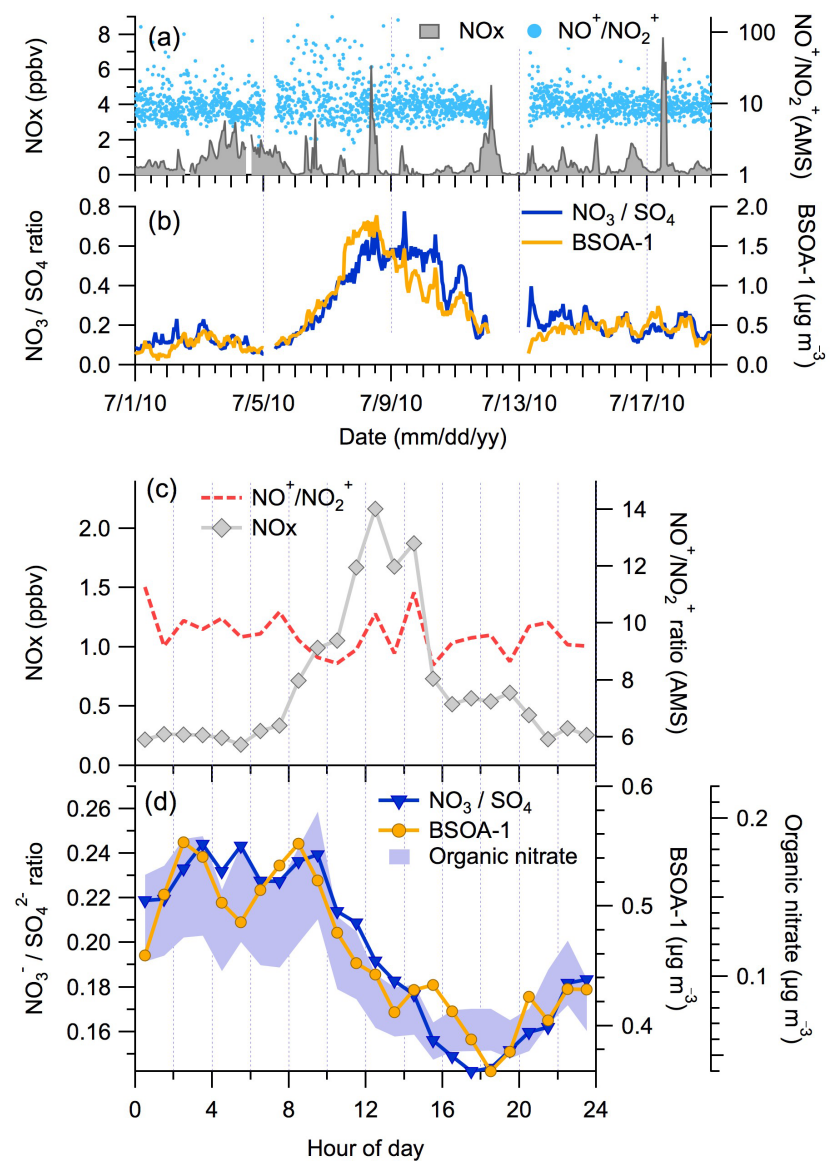

Figure 5. Time series (PST) profiles of (a) $\mathrm{NO}_{x}$ mixing ratio and $\mathrm{NO}^{+} / \mathrm{NO}_{2}^{+}$ratio measured by HR-ToF-AMS and (b) $\mathrm{NO}_{3}^{-} / \mathrm{SO}_{4}^{2-}$ ratio and mass loading of BSOA-1. Diurnal cycles of (c) $\mathrm{NO}_{x}$ mixing ratio and $\mathrm{NO}^{+} / \mathrm{NO}_{2}^{+}$ratio measured by HR-ToF-AMS and (d) $\mathrm{NO}_{3}^{-} / \mathrm{SO}_{4}^{2-}$ ratio and mass loadings of BSOA-1 and organic nitrates in Period 2.

be estimated using the calculation approach used by $\mathrm{Xu}$ et al. (2015) (see details in the Supplement) and assuming the subtracted $\mathrm{NO}^{+}$and $\mathrm{NO}_{2}^{+}$signal originated solely from organic nitrates and the molecular weight of the organic nitrates to be $200-300 \mathrm{~g} \mathrm{~mol}^{-1}$. The organic nitrate mass accounted for $22-33 \%$ of BSOA-1 at night, representing the upper limit, and its diurnal cycle (ranging from 0.05 to $0.2 \mu \mathrm{g} \mathrm{m}^{-3}$ ) is shown in Fig. 5d. Results of these calculations suggest that organic nitrates can be a significant contributor to BSOA mass produced via nighttime $\mathrm{NO}_{3} \cdot$ chemistry. Similarly, $\mathrm{Xu}$ et al. (2015) estimated that the organic nitrates accounted for $20-30 \%$ of less-oxidized OOA (LO-OOA) mass observed during the nighttime.

\subsection{Comparison to previous laboratory studies}

Potential formation pathways of BSOA can be evaluated through examination of specific mass fragments. Organic fragments at $m / z 91$ have been observed in laboratory- 
generated and ambient BSOA, and the BSOA-1 and BSOA-2 factors have a distinct peak at $m / z, 91$ mostly due to the presence of the $\mathrm{C}_{7} \mathrm{H}_{7}^{+}$fragment (Fig. 3). Although major contributors of $\mathrm{C}_{7} \mathrm{H}_{7}^{+}$observed in this study are not well characterized, it is well known that formation of tropylium ion $\left(\mathrm{C}_{7} \mathrm{H}_{7}^{+}\right)$ by electron impact ionization of benzyl compounds can attribute to this organic fragment (McLafferty and Turecek, 1993). While combustion processes are major sources of aromatic compounds, Gratien et al. (2011) observed formation of $p$-cymene via oxidation of $\alpha$-pinene in laboratory experiments, suggesting possible biogenic origins of aromatic compounds. Other terpenes perhaps undergo similar chemistry but their atmospheric significance remains unclear.

Even though the mass fraction of $\mathrm{m} / \mathrm{z}, 91$ to total organic $\left(f_{91}\right)$ is not a unique tracer for BSOA ( $\mathrm{Ng}$ et al., 2011), $f_{91}$ can be potentially used to evaluate formation pathways of BSOA in this unpolluted, biogenic-rich environment (e.g. evaluate relative importance of BSOA formation pathways and precursors). The $f_{91}$ values of both raw data and PMF results are shown in Fig. 6 along with $f_{91}$ values from previously published laboratory and field studies. Recent intercomparison of Aerodyne aerosol chemical speciation monitors (ACMS) highlighted a significant variability of mass fraction of specific $\mathrm{m} / \mathrm{z}$, to total organic between instruments (Fröhlich et al., 2015), and hence the comparisons of $f_{91}$ values between studies are only semiquantitative. Nevertheless, Chen et al. (2015) reported that the $f_{91}$ value of $\alpha$-pinene SOA generated in smog chamber experiments at low $\mathrm{NO}_{x}$ conditions is much lower than $\beta$-caryophyllene SOA generated in the same study. Previous plant chamber experiments (i.e. oxidation of a mixture of BVOCs) further suggest that the value of $f_{91}$ likely depends on the relative contribution of sesquiterpenes to total BVOCs; the average value of $f_{91}$ of SOA generated by the oxidation of different plant emissions is reported here (Kiendler-Scharr et al., 2009). The above observations indicate that sesquiterpenes may play an important role to the production of $m / z 91$ (or $\mathrm{C}_{7} \mathrm{H}_{7}^{+}$fragments) observed in Whistler and other forest region such as a boreal forest in Finland (Finessi et al., 2012).

Laboratory studies have also shown that some of the firstgeneration products of $\alpha$-pinene ozonolysis can have a relatively high level of $f_{91}$ in their AMS spectra, including cis-pinonic acid droplets generated by atomization (Lee et al., 2012) and pinonaldehyde uptake to sulfuric acid particles (Liggio and Li, 2006). Although cis-pinonic acid and pinonaldehyde are rather volatile, they may experience significant wall loss in smog chambers during the SOA formation experiments previously reported (Müller et al., 2012; Zhang et al., 2015). The wall effect can suppress subsequent gas-phase reactions of intermediate products that may produce less volatile, SOA-forming organic acids with the same $f_{91}$ signature. Since the surface characteristics of the land and vegetation in the remote forested region can be very different to the wall surface of smog chambers, $\alpha$-pinene is pos-

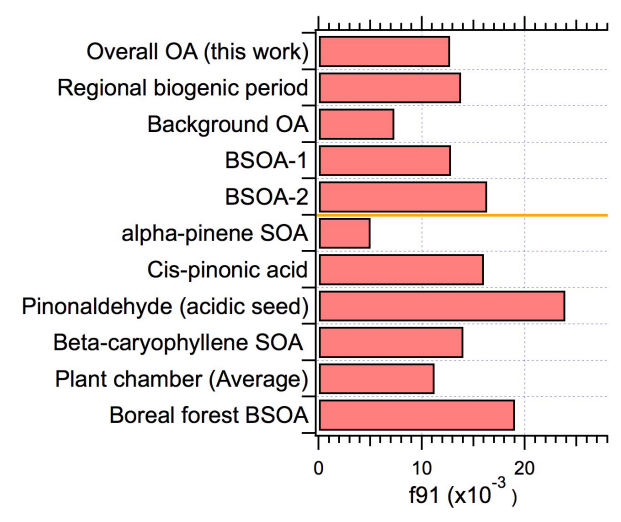

Figure 6. The mass fraction of $m / z, 91\left(f_{91}\right)$ observed in this study (overall OA, regional biogenic period, background OA, BSOA-1, and BSOA-2), $\alpha$-pinene and $\beta$-caryophyllene SOA generated by chamber experiments (Chen et al., 2015), pinonaldehyde uptake on sulfuric acid seeds (Liggio and Li, 2006), plant chamber SOA (Kiendler-Scharr et al., 2009), cis-pinonic acid (Lee et al., 2012), and BSOA observed in boreal forest in Finland (Finessi et al., 2012).

sibly an important precursor of $\mathrm{C}_{7} \mathrm{H}_{7}^{+}$fragments in the real atmosphere.

The difference in the $f_{91}$ values between BSOA-1 and BSOA-2 can be further used to evaluate the relationship between these two PMF factors. In the same campaign in Whistler, Slowik et al. (2012) performed a set of in situ heterogeneous $\mathrm{OH}$ oxidation experiments using a flow tube reactor to age BSOA sampled during the biogenic period. They clearly observed that the $f_{91}$ value declined with heterogeneous oxidation and the mass spectra of reaction products determined by PMF analysis did not contain a high value of $f_{91}$. Because BSOA-2 has a higher level of $f_{91}$ than BSOA-1 (Fig. 6), we conclude that there is little heterogeneous oxidative conversion of BSOA-1 to BSOA-2.

\section{Conclusions and atmospheric implications}

The strong biogenic episode observed in this study provides a unique opportunity to improve current understanding of BSOA formation chemistry in a coniferous forest. The high levels of SOA formation are comparable to those previously observed in the summertime in another Canadian forested location also dominated by terpene emissions (Slowik et al., 2010). Given the considerable emphasis placed on isoprene SOA in the past few years and given the high SOA levels observed in this study, there is merit to addressing the formation of SOA in these coniferous forested regions. Indeed, with pronounced high-latitude warming it is very important to better understand SOA formation in such regions to know how they will respond to changing climate conditions (Leaitch et al., 2011).

The BSOA observed during the biogenic episode was primarily due to ozonolysis and $\mathrm{OH}$ oxidation of BVOCs (i.e. 
monoterpenes and perhaps sesquiterpenes) during the day. We also provide evidence that nitrate radical chemistry with BVOCs at night can be significant. PMF analysis identified two types of BSOA, namely BSOA-1 and BSOA-2, and separated them from the background organic aerosol. BSOA1 represents gas-phase ozonolysis and nitrate radical oxidation products, and is likely semivolatile in nature, resulting in higher concentrations at low ambient temperature during the night. BSOA-2 has a much stronger $\mathrm{CO}_{2}^{+}$signal than BSOA1 , and consists of products from gas-phase oxidation by $\mathrm{OH}$ radical and ozone during the day. Hence, the temporal variations of BSOA-1 and BSOA-2 observed here are due to their gas-particle partitioning in response to ambient temperature, the relative importance of different oxidation chemistry between day and night, and the gradual oxidation of earlygeneration gas-phase oxidation products. The calculation in Sect. 3.4 suggests that BSOA-1 can be largely contributed by organic nitrates at night ( $22-33 \%$ by mass) due to nitrate radical chemistry.

This study evaluates the values of $f_{91}$ obtained from the AMS measurements as a tracer to investigate the BSOA-2 potential formation pathways. We demonstrated that heterogeneous oxidation of BSOA-1 is expected to be a minor production pathway of BSOA-2. Nevertheless, we cannot rule out the possibility that some BSOA-1 material repartitions to the gas phase due to elevated temperature during the daytime and then undergoes gas-phase oxidation to produce BSOA2 materials. This may partly explain the decay of BSOA-1 and a higher level of BSOA-2 observed in the later period of the biogenic episode. Although sesquiterpenes were not measured in this study, they can be potentially important to generate BSOA with distinct peak at $m / z 91$ (or $\mathrm{C}_{7} \mathrm{H}_{7}^{+}$fragments) based on previous laboratory observations. Moreover, recently chamber experiments suggested that high signals at $\mathrm{C}_{7} \mathrm{H}_{7}^{+}$in ambient aerosol mass spectrum can be potentially used to indicate the presence of SOA products generated from $\beta$-pinene and nitrate radical reactions (Boyd et al., 2015).

\section{The Supplement related to this article is available online at doi:10.5194/acp-16-6721-2016-supplement.}

Acknowledgements. This work was funded by Environment Canada, Canadian Foundation for Climate and Atmospheric Science (CFCAS), and Natural Science and Engineering Research Council (NSERC). Environment Canada funded the Whistler Aerosol and Cloud Study 2010 through the Clean Air Regulatory Agenda (CARA). Funding was provided through Environment Canada's Grants and Contribution program for JPDA and AKYL (G \& C 1004932).

Edited by: U. Baltensperger

\section{References}

Ahlm, L., Shakya, K. M., Russell, L. M., Schroder, J. C., Wong, J. P. S., Sjostedt, S. J., Hayden, K. L., Liggio, J., Wentzell, J. J. B., Wiebe, H. A., Mihele, C., Leaitch, W. R., and Macdonald, A. M.: Temperature-dependent accumulation mode particle and cloud nuclei concentrations from biogenic sources during WACS 2010, Atmos. Chem. Phys., 13, 3393-3407, doi:10.5194/acp-13-33932013, 2013.

Aiken, A. C., Decarlo, P. F., Kroll, J. H., Worsnop, D. R., Huffman, J. A., Docherty, K. S., Ulbrich, I. M., Mohr, C., Kimmel, J. R., Sueper, D., Sun, Y., Zhang, Q., Trimborn, A., Northway, M., Ziemann, P. J., Canagaratna, M. R., Onasch, T. B., Alfarra, M. R., Prevot, A. S. H., Dommen, J., Duplissy, J., Metzger, A., Baltensperger, U., and Jimenez, J. L.: O/C and OM/OC ratios of primary, secondary, and ambient organic aerosols with high-resolution time-of-flight aerosol mass spectrometry, Environ. Sci. Technol., 42, 4478-4485, 2008.

Allan, J., Delia, A., Coe, H., Bower, K., Alfarra, M., Jimenez, J., Middlebrook, A., Drewnick, F., Onasch, T., Canagaratna, M., Jayne, J., and Worsnop, D.: A generalised method for the extraction of chemically resolved mass spectra from aerodyne aerosol mass spectrometer data, J. Aerosol Sci., 35, 909-922, 2004.

Berresheim, H., Elste, T., Plass-Dulmer, C., Eisele, F. L., and Tanner, D. J.: Chemical ionization mass spectrometer for long-term measurements of atmospheric $\mathrm{OH}$ and $\mathrm{H}_{2} \mathrm{SO}_{4}$, Int. J. Mass Spectrom., 202, 91-109, 2000.

Blake, R. S., Monks, P. S., and Ellis, A. M.: Proton-Transfer Reaction Mass Spectrometry, Chem. Rev., 109, 861-896, 2009.

Boyd, C. M., Sanchez, J., Xu, L., Eugene, A. J., Nah, T., Tuet, W. Y., Guzman, M. I., and Ng, N. L.: Secondary organic aerosol formation from the $\beta$-pinene $+\mathrm{NO}_{3}$ system: effect of humidity and peroxy radical fate, Atmos. Chem. Phys., 15, 7497-7522, doi:10.5194/acp-15-7497-2015, 2015.

Canagaratna, M. R., Jimenez, J. L., Kroll, J. H., Chen, Q., Kessler, S. H., Massoli, P., Hildebrandt Ruiz, L., Fortner, E., Williams, L. R., Wilson, K. R., Surratt, J. D., Donahue, N. M., Jayne, J. T., and Worsnop, D. R.: Elemental ratio measurements of organic compounds using aerosol mass spectrometry: characterization, improved calibration, and implications, Atmos. Chem. Phys., 15, 253-272, doi:10.5194/acp-15-253-2015, 2015.

Chen, Q., Farmer, D. K., Schneider, J., Zorn, S. R., Heald, C. L., Karl, T. G., Guenther, A., Allan, J. D., Robinson, N., Coe, H., Kimmel, J. R., Pauliquevis, T., Borrmann, S., Poeschl, U., Andreae, M. O., Artaxo, P., Jimenez, J. L., and Martin, S. T.: Mass spectral characterization of submicron biogenic organic particles in the Amazon Basin, Geophys. Res. Lett., 36, L20806, doi:10.1029/2009GL039880, 2009.

Chen, Q., Farmer, D. K., Rizzo, L. V., Pauliquevis, T., Kuwata, M., Karl, T. G., Guenther, A., Allan, J. D., Coe, H., Andreae, M. O., Pöschl, U., Jimenez, J. L., Artaxo, P., and Martin, S. T.: Submicron particle mass concentrations and sources in the Amazonian wet season (AMAZE-08), Atmos. Chem. Phys., 15, 3687-3701, doi:10.5194/acp-15-3687-2015, 2015.

Chhabra, P. S., Flagan, R. C., and Seinfeld, J. H.: Elemental analysis of chamber organic aerosol using an aerodyne high-resolution aerosol mass spectrometer, Atmos. Chem. Phys., 10, 4111-4131, doi:10.5194/acp-10-4111-2010, 2010.

DeCarlo, P. F., Kimmel, J. R., Trimborn, A., Northway, M. J., Jayne, J. T., Aiken, A. C., Gonin, M., Fuhrer, K., Horvath, T., Docherty, 
K. S., Worsnop, D. R., and Jimenez, J. L.: Field-deployable, high-resolution, time-of-flight aerosol mass spectrometer, Anal. Chem., 78, 8281-8289, 2006.

de Gouw, J. and Warneke, C.: Measurements of volatile organic compounds in the earths atmosphere using proton-transferreaction mass spectrometry, Mass Spectrom. Rev., 26, 223-257, 2007.

Donahue, N. M., Kroll, J. H., Pandis, S. N., and Robinson, A. L.: A two-dimensional volatility basis set - Part 2: Diagnostics of organic-aerosol evolution, Atmos. Chem. Phys., 12, 615-634, doi:10.5194/acp-12-615-2012, 2012.

Ehn, M., Kleist, E., Junninen, H., Petäjä, T., Lönn, G., Schobesberger, S., Dal Maso, M., Trimborn, A., Kulmala, M., Worsnop, D. R., Wahner, A., Wildt, J., and Mentel, Th. F.: Gas phase formation of extremely oxidized pinene reaction products in chamber and ambient air, Atmos. Chem. Phys., 12, 5113-5127, doi:10.5194/acp-12-5113-2012, 2012.

Ehn, M., Thornton, J. A., Kleist, E., Sipila, M., Junninen, H., Pullinen, I., Springer, M., Rubach, F., Tillmann, R., Lee, B., Lopez-Hilfiker, F., Andres, S., Acir, I., Rissanen, M., Jokinen, T., Schobesberger, S., Kangasluoma, J., Kontkanen, J., Nieminen, T., Kurten, T., Nielsen, L. B., Jorgensen, S., Kjaergaard, H. G., Canagaratna, M., Dal Maso, M., Berndt, T., Petaja, T., Wahner, A., Kerminen, V., Kulmala, M., Worsnop, D. R., Wildt, J., and Mentel, T. F.: A large source of low-volatility secondary organic aerosol, Nature, 506, 476-479, doi:10.1038/nature13032, 2014.

Farmer, D. K., Matsunaga, A., Docherty, K. S., Surratt, J. D., Seinfeld, J. H., Ziemann, P. J., and Jimenez, J. L.: Response of an aerosol mass spectrometer to organonitrates and organosulfates and implications for atmospheric chemistry, P. Natl. Acad. Sci. USA, 107, 6670-6675, 2010.

Finessi, E., Decesari, S., Paglione, M., Giulianelli, L., Carbone, C., Gilardoni, S., Fuzzi, S., Saarikoski, S., Raatikainen, T., Hillamo, R., Allan, J., Mentel, Th. F., Tiitta, P., Laaksonen, A., Petäjä, T., Kulmala, M., Worsnop, D. R., and Facchini, M. C.: Determination of the biogenic secondary organic aerosol fraction in the boreal forest by NMR spectroscopy, Atmos. Chem. Phys., 12, 941-959, doi:10.5194/acp-12-941-2012, 2012.

Fröhlich, R., Crenn, V., Setyan, A., Belis, C. A., Canonaco, F., Favez, O., Riffault, V., Slowik, J. G., Aas, W., Aijälä, M., Alastuey, A., Artiñano, B., Bonnaire, N., Bozzetti, C., Bressi, M., Carbone, C., Coz, E., Croteau, P. L., Cubison, M. J., Esser-Gietl, J. K., Green, D. C., Gros, V., Heikkinen, L., Herrmann, H., Jayne, J. T., Lunder, C. R., Minguillón, M. C., Močnik, G., O’Dowd, C. D., Ovadnevaite, J., Petralia, E., Poulain, L., Priestman, M., Ripoll, A., Sarda-Estève, R., Wiedensohler, A., Baltensperger, U., Sciare, J., and Prévôt, A. S. H.: ACTRIS ACSM intercomparison - Part 2: Intercomparison of ME-2 organic source apportionment results from 15 individual, co-located aerosol mass spectrometers, Atmos. Meas. Tech., 8, 2555-2576, doi:10.5194/amt8-2555-2015, 2015.

Fry, J. L., Kiendler-Scharr, A., Rollins, A. W., Wooldridge, P. J., Brown, S. S., Fuchs, H., Dubé, W., Mensah, A., dal Maso, M., Tillmann, R., Dorn, H.-P., Brauers, T., and Cohen, R. C.: Organic nitrate and secondary organic aerosol yield from $\mathrm{NO}_{3}$ oxidation of $\beta$-pinene evaluated using a gas-phase kinetics/aerosol partitioning model, Atmos. Chem. Phys., 9, 14311449, doi:10.5194/acp-9-1431-2009, 2009.
Goldstein, A. H., Koven, C. D., Heald, C. L., and Fung, I. Y.: Biogenic carbon and anthropogenic pollutants combine to form a cooling haze over the southeastern United States, P. Natl. Acad. Sci. USA, 106, 8835-8840, 2009.

Gratien, A., Johnson, S. N., Ezell, M. J., Dawson, M. L., Bennett, R., and Finlayson-Pitts, B. J.: Surprising formation of $p$-cymene in the oxidation of alpha-pinene in air by the atmospheric oxidants $\mathrm{OH}, \mathrm{O}_{3}$, and $\mathrm{NO}_{3}$, Environ. Sci. Technol., 45, 2755-2760, 2011.

Hallquist, M., Wenger, J. C., Baltensperger, U., Rudich, Y., Simpson, D., Claeys, M., Dommen, J., Donahue, N. M., George, C., Goldstein, A. H., Hamilton, J. F., Herrmann, H., Hoffmann, T., Iinuma, Y., Jang, M., Jenkin, M. E., Jimenez, J. L., Kiendler-Scharr, A., Maenhaut, W., McFiggans, G., Mentel, Th. F., Monod, A., Prévôt, A. S. H., Seinfeld, J. H., Surratt, J. D., Szmigielski, R., and Wildt, J.: The formation, properties and impact of secondary organic aerosol: current and emerging issues, Atmos. Chem. Phys., 9, 5155-5236, doi:10.5194/acp-9-51552009, 2009.

Han, Y., Iwamoto, Y., Nakayama, T., Kawamura, K., and Mochida, M.: Formation and evolution of biogenic secondary organic aerosol over a forest site in Japan, J. Geophys. Res.-Atmos., 119, 259-273, 2014.

Harrison, D., Hunter, M. C., Lewis, A. C., Seakins, P. W., Bonsang, B., Gros, V., Kanakidou, M., Touaty, M., Kavouras, I., Mihalopoulos, N., Stephanou, E., Alves, C., Nunes, T., and Pio, C.: Ambient isoprene and monoterpene concentrations in a Greek fir (Abies Borisii-regis) forest. Reconciliation with emissions measurements and effects on measured $\mathrm{OH}$ concentrations, Atmos. Environ., 35, 4699-4711, 2001.

Hu, W. W., Campuzano-Jost, P., Palm, B. B., Day, D. A., Ortega, A. M., Hayes, P. L., Krechmer, J. E., Chen, Q., Kuwata, M., Liu, Y. J., de Sá, S. S., McKinney, K., Martin, S. T., Hu, M., Budisulistiorini, S. H., Riva, M., Surratt, J. D., St. Clair, J. M., Isaacman-Van Wertz, G., Yee, L. D., Goldstein, A. H., Carbone, S., Brito, J., Artaxo, P., de Gouw, J. A., Koss, A., Wisthaler, A., Mikoviny, T., Karl, T., Kaser, L., Jud, W., Hansel, A., Docherty, K. S., Alexander, M. L., Robinson, N. H., Coe, H., Allan, J. D., Canagaratna, M. R., Paulot, F., and Jimenez, J. L.: Characterization of a real-time tracer for isoprene epoxydiols-derived secondary organic aerosol (IEPOX-SOA) from aerosol mass spectrometer measurements, Atmos. Chem. Phys., 15, 11807-11833, doi:10.5194/acp-15-11807-2015, 2015.

Huffman, J. A., Docherty, K. S., Aiken, A. C., Cubison, M. J., Ulbrich, I. M., DeCarlo, P. F., Sueper, D., Jayne, J. T., Worsnop, D. R., Ziemann, P. J., and Jimenez, J. L.: Chemically-resolved aerosol volatility measurements from two megacity field studies, Atmos. Chem. Phys., 9, 7161-7182, doi:10.5194/acp-9-71612009, 2009.

Kanakidou, M., Seinfeld, J. H., Pandis, S. N., Barnes, I., Dentener, F. J., Facchini, M. C., Van Dingenen, R., Ervens, B., Nenes, A., Nielsen, C. J., Swietlicki, E., Putaud, J. P., Balkanski, Y., Fuzzi, S., Horth, J., Moortgat, G. K., Winterhalter, R., Myhre, C. E. L., Tsigaridis, K., Vignati, E., Stephanou, E. G., and Wilson, J.: Organic aerosol and global climate modelling: a review, Atmos. Chem. Phys., 5, 1053-1123, doi:10.5194/acp-5-1053-2005, 2005.

Kiendler-Scharr, A., Zhang, Q., Hohaus, T., Kleist, E., Mensah, A., Mentel, T. F., Spindler, C., Uerlings, R., Tillmann, R., and Wildt, 
J.: Aerosol Mass Spectrometric Features of Biogenic SOA: Observations from a Plant Chamber and in Rural Atmospheric Environments, Environ. Sci. Technol., 43, 8166-8172, 2009.

Leaitch, W. R., Macdonald, A. M., Brickell, P. C., Liggio, J., Sjostedt, S. J., Vlasenko, A., Bottenheim, J. W., Huang, L., Li, S.M., Liu, P. S. K., Toom-Sauntry, D., Hayden, K. A., Sharma, S., Shantz, N. C., Wiebe, H. A., Zhang, W., Abbatt, J. P. D., Slowik, J. G., Chang, R. Y. W., Russell, L. M., Schwartz, R. E., Takahama, S., Jayne, J. T., and Ng, N. L.: Temperature response of the submicron organic aerosol from temperate forests, Atmos. Environ., 45, 6696-6704, doi:10.1016/j.atmosenv.2011.08.047, 2011.

Lee, A., Goldstein, A. H., Keywood, M. D., Gao, S., Varutbangkul, V., Bahreini, R., Ng, N. L., Flagan, R. C., and Seinfeld, J. H.: Gas-phase products and secondary aerosol yields from the ozonolysis of ten different terpenes, J. Geophys. Res.-Atmos., 111, D07302, doi:10.1029/2005JD006437, 2006a.

Lee, A., Goldstein, A. H., Kroll, J. H., Ng, N. L., Varutbangkul, V., Flagan, R. C., and Seinfeld, J. H.: Gas-phase products and secondary aerosol yields from the photooxidation of 16 different terpenes, J. Geophys. Res.-Atmos., 111, D17305, doi:10.1029/2006JD007050, 2006b.

Lee, A. K. Y., Hayden, K. L., Herckes, P., Leaitch, W. R., Liggio, J., Macdonald, A. M., and Abbatt, J. P. D.: Characterization of aerosol and cloud water at a mountain site during WACS 2010: secondary organic aerosol formation through oxidative cloud processing, Atmos. Chem. Phys., 12, 7103-7116, doi:10.5194/acp-12-7103-2012, 2012.

Liggio, J. and Li, S.: Reactive uptake of pinonaldehyde on acidic aerosols, J. Geophys. Res.-Atmos., 111, D24303, doi:10.1029/2005JD006978, 2006.

Martin, S. T., Andreae, M. O., Althausen, D., Artaxo, P., Baars, H., Borrmann, S., Chen, Q., Farmer, D. K., Guenther, A., Gunthe, S. S., Jimenez, J. L., Karl, T., Longo, K., Manzi, A., Müller, T., Pauliquevis, T., Petters, M. D., Prenni, A. J., Pöschl, U., Rizzo, L. V., Schneider, J., Smith, J. N., Swietlicki, E., Tota, J., Wang, J., Wiedensohler, A., and Zorn, S. R.: An overview of the Amazonian Aerosol Characterization Experiment 2008 (AMAZE08), Atmos. Chem. Phys., 10, 11415-11438, doi:10.5194/acp10-11415-2010, 2010.

McLafferty, L. W. and Turecek, F.: Interpretation of Mass Spectra, University Science Books, Mill Valley, CA, 238-240, 1993.

Müller, L., Reinnig, M.-C., Naumann, K. H., Saathoff, H., Mentel, T. F., Donahue, N. M., and Hoffmann, T.: Formation of 3-methyl1,2,3-butanetricarboxylic acid via gas phase oxidation of pinonic acid - a mass spectrometric study of SOA aging, Atmos. Chem. Phys., 12, 1483-1496, doi:10.5194/acp-12-1483-2012, 2012.

Ng, N. L., Kwan, A. J., Surratt, J. D., Chan, A. W. H., Chhabra, P. S., Sorooshian, A., Pye, H. O. T., Crounse, J. D., Wennberg, P. O., Flagan, R. C., and Seinfeld, J. H.: Secondary organic aerosol (SOA) formation from reaction of isoprene with nitrate radicals $\left(\mathrm{NO}_{3}\right)$, Atmos. Chem. Phys., 8, 4117-4140, doi:10.5194/acp-8-4117-2008, 2008.

Ng, N. L., Canagaratna, M. R., Zhang, Q., Jimenez, J. L., Tian, J., Ulbrich, I. M., Kroll, J. H., Docherty, K. S., Chhabra, P. S., Bahreini, R., Murphy, S. M., Seinfeld, J. H., Hildebrandt, L., Donahue, N. M., DeCarlo, P. F., Lanz, V. A., Prévôt, A. S. H., Dinar, E., Rudich, Y., and Worsnop, D. R.: Organic aerosol components observed in Northern Hemispheric datasets from
Aerosol Mass Spectrometry, Atmos. Chem. Phys., 10, 46254641, doi:10.5194/acp-10-4625-2010, 2010.

Ng, N. L., Canagaratna, M. R., Jimenez, J. L., Zhang, Q., Ulbrich, I. M., and Worsnop, D. R.: Real-time methods for estimating organic component mass concentrations from aerosol mass spectrometer data, Environ. Sci. Technol., 45, 910-916, 2011.

Paatero, P. and Tapper, U.: Positive matrix factorization: A nonnegative factor model with optimal utilization of error estimate of data values, Environmetrics, 5, 111-126, 1994.

Pierce, J. R., Leaitch, W. R., Liggio, J., Westervelt, D. M., Wainwright, C. D., Abbatt, J. P. D., Ahlm, L., Al-Basheer, W., Cziczo, D. J., Hayden, K. L., Lee, A. K. Y., Li, S.-M., Russell, L. M., Sjostedt, S. J., Strawbridge, K. B., Travis, M., Vlasenko, A., Wentzell, J. J. B., Wiebe, H. A., Wong, J. P. S., and Macdonald, A. M.: Nucleation and condensational growth to $\mathrm{CCN}$ sizes during a sustained pristine biogenic SOA event in a forested mountain valley, Atmos. Chem. Phys., 12, 3147-3163, doi:10.5194/acp-12-3147-2012, 2012.

Rinne, H., Guenther, A., Greenberg, J., and Harley, P.: Isoprene and monoterpene fluxes measured above Amazonian rainforest and their dependence on light and temperature, Atmos. Environ., 36, 2421-2426, 2002.

Robinson, N. H., Hamilton, J. F., Allan, J. D., Langford, B., Oram, D. E., Chen, Q., Docherty, K., Farmer, D. K., Jimenez, J. L., Ward, M. W., Hewitt, C. N., Barley, M. H., Jenkin, M. E., Rickard, A. R., Martin, S. T., McFiggans, G., and Coe, H.: Evidence for a significant proportion of Secondary Organic Aerosol from isoprene above a maritime tropical forest, Atmos. Chem. Phys., 11, 1039-1050, doi:10.5194/acp-11-1039-2011, 2011.

Setyan, A., Zhang, Q., Merkel, M., Knighton, W. B., Sun, Y., Song, C., Shilling, J. E., Onasch, T. B., Herndon, S. C., Worsnop, D. R., Fast, J. D., Zaveri, R. A., Berg, L. K., Wiedensohler, A., Flowers, B. A., Dubey, M. K., and Subramanian, R.: Characterization of submicron particles influenced by mixed biogenic and anthropogenic emissions using high-resolution aerosol mass spectrometry: results from CARES, Atmos. Chem. Phys., 12, 8131-8156, doi:10.5194/acp-12-8131-2012, 2012.

Shilling, J. E., Chen, Q., King, S. M., Rosenoern, T., Kroll, J. H., Worsnop, D. R., DeCarlo, P. F., Aiken, A. C., Sueper, D., Jimenez, J. L., and Martin, S. T.: Loading-dependent elemental composition of $\alpha$-pinene SOA particles, Atmos. Chem. Phys., 9, 771-782, doi:10.5194/acp-9-771-2009, 2009.

Shilling, J. E., Zaveri, R. A., Fast, J. D., Kleinman, L., Alexander, M. L., Canagaratna, M. R., Fortner, E., Hubbe, J. M., Jayne, J. T., Sedlacek, A., Setyan, A., Springston, S., Worsnop, D. R., and Zhang, Q.: Enhanced SOA formation from mixed anthropogenic and biogenic emissions during the CARES campaign, Atmos. Chem. Phys., 13, 2091-2113, doi:10.5194/acp-13-20912013, 2013.

Sjostedt, S. J., Huey, L. G., Tanner, D. J., Peischl, J., Chen, G., Dibb, J. E., Lefer, B., Hutterli, M. A., Beyersdorf, A. J., Blake, N. J., Blake, D. R., Sueper, D., Ryerson, T., Burkhart, J., and Stohl, A.: Observations of hydroxyl and the sum of peroxy radicals at Summit, Greenland during summer 2003, Atmos. Environ., 41, 5122-5137, 2007.

Slowik, J. G., Stroud, C., Bottenheim, J. W., Brickell, P. C., Chang, R. Y.-W., Liggio, J., Makar, P. A., Martin, R. V., Moran, M. D., Shantz, N. C., Sjostedt, S. J., van Donkelaar, A., Vlasenko, A., Wiebe, H. A., Xia, A. G., Zhang, J., Leaitch, W. R., and Ab- 
batt, J. P. D.: Characterization of a large biogenic secondary organic aerosol event from eastern Canadian forests, Atmos. Chem. Phys., 10, 2825-2845, doi:10.5194/acp-10-2825-2010, 2010.

Slowik, J. G., Wong, J. P. S., and Abbatt, J. P. D.: Real-time, controlled $\mathrm{OH}$-initiated oxidation of biogenic secondary organic aerosol, Atmos. Chem. Phys., 12, 9775-9790, doi:10.5194/acp12-9775-2012, 2012.

Tanner, D. J., Jefferson, A., and Eisele, F. L.: Selected ion chemical ionization mass spectrometric measurement of $\mathrm{OH}, \mathrm{J}$. Geophys. Res.-Atmos., 102, 6415-6425, 1997.

Ulbrich, I. M., Canagaratna, M. R., Zhang, Q., Worsnop, D. R., and Jimenez, J. L.: Interpretation of organic components from Positive Matrix Factorization of aerosol mass spectrometric data, Atmos. Chem. Phys., 9, 2891-2918, doi:10.5194/acp-9-2891-2009, 2009.
Xu, L., Guo, H., Boyd, C. M., Klein, M., Bougiatioti, A., Cerully, K. M., Hite, J. R., Isaacman-VanWertz, G., Kreisberg, N. M., Knote, C., Olson, K., Koss, A., Goldstein, A. H., Hering, S. V., de Gouw, J., Baumann, K., Lee, S., Nenes, A., Weber, R. J., and Ng, N. L.: Effects of anthropogenic emissions on aerosol formation from isoprene and monoterpenes in the southeastern United States, $\mathrm{P}$ Natl. Acad. Sci. USA, 112, 37-42, 2015.

Zhang, X., Cappa, C. D., Jathar, S. H., McVay, R. C., Ensberg, J. J., Kleeman, M. J., and Seinfeld, J. H.: Influence of vapor wall loss in laboratory chambers on yields of secondary organic aerosol, $\mathrm{P}$. Natl. Acad. Sci. USA, 111, 5802-5807, 2014.

Zhang, X., Schwantes, R. H., McVay, R. C., Lignell, H., Coggon, M. M., Flagan, R. C., and Seinfeld, J. H.: Vapor wall deposition in Teflon chambers, Atmos. Chem. Phys., 15, 4197-4214, doi:10.5194/acp-15-4197-2015, 2015. 